\title{
The European Social Dialogue in the Shadow of Hierarchy
}

\author{
STIJN SMISMANS Law School, University of Cardiff
}

\begin{abstract}
The European social dialogue provides for the signing of collective agreements between employers' associations and trade unions organised at the European level. Effectiveness to a great extent depends on the shadow of hierarchy, which is cast by the threat of legislative action and by ensuring implementation of collective agreements through public intervention. The need for the shadow is illustrated by the initial priority given to statutory agreements and the problems of implementation of more recent nonstatutory agreements. While the shadow of hierarchy is important to ensure the effectiveness of social dialogue, social dialogue procedures are not characterised by strong principal-agent relationships. In particular, nonstatutory agreements stem from a bottom-up private sector-inspired tradition of industrial relations. Even in the case of statutory agreements, the European Commission, as principal, does not appoint the agent and the delegation is implicit rather than explicit. Moreover, successful delegation entirely depends on whether the agents reach agreement between themselves. While the Commission could revoke delegation if Community objectives are not realised and by setting statutory criteria for implementing an agreement, its room for manoeuvre is limited for reasons of political pragmatism.
\end{abstract}

\section{Introduction}

The European social dialogue provides for the signing of collective agreements between employers' associations and trade unions organised at the European level. ${ }^{\mathrm{I}}$ Such agreements constitute a form of governance clearly limited to the sectoral area of the employment relationship and occurring outside the main political legislative avenue of decisionmaking. Collective agreements have become part of the institutional reality since the introduction of the 'European social dialogue' provisions in the Social Agreement attached to the Maastricht Treaty-subsequently introduced in Articles 138-9 EC Treaty. These provisions allow for four procedural types of European collective agreements (CAs). 
COCOCAs are Commission-initiated and Council-implemented CAs. According to the EG Treaty, the Commission has to consult the European social partners on all legislative initiatives in the social policy field. During consultation, the European social partners may express their desire to deal with the issue by European collective agreement rather than by legislation. In this case the Commission will suspend its legislative action; if the social partners reach an agreement this solution will be preferred to legislative action. In order to implement this type of European collective agreement, the European social partners can request that the European Commission and the Council adopt their agreement by a Council directive, in which case the agreement will have the same effect as European legislation and will be binding for all member states, which can be penalised in court for non-implementation. This solution is inspired by national industrial relations systems which provide strong public intervention to give effect erga omnes to collective agreements.

COSICAs are Commission-initiated but self-implemented CAs. As in the first case, the European social partners sign a collective agreement following consultation by the Commission on a proposal for social legislation. However, instead of asking the Commission and the Council to implement the agreement with a directive, the European social partners decide to implement the agreement themselves by relying on their national member organisations and the legal instruments and institutional infrastructure of industrial relations available in the member states. In this case, the agreement does not become part of Community law, and the possibility to punish non-implementation through court action appears very limited (Treu I996: I72; Schiek 2005).

SISICAs are self-initiated and self-implemented CAs. European collective agreements do not need to originate in an initial consultation by the Commission on a legislative proposal. The European social partners are entirely free to take the initiative to enter into negotiations and sign an agreement on the matters they consider appropriate. They can subsequently implement such a European collective agreement with the instruments of industrial relations available to their member organisations at the national level.

SICOCAs are self-initiated but Council-implemented CAs. As in the preceding case, the European social partners take the initiative themselves to negotiate on an issue. However, rather than implementing the signed agreement autonomously, namely with the instruments of industrial relations available to their national member organisations, the European social partners can request the implementation of the European agreement by Council directive, provided that the content of the agreement falls within the competence of the Community. 
The relationship between 'sectoral governance' and 'territorially bound democratic government' in the European social dialogue is thus characterised by two dimensions. Firstly, public authority, and in particular the European Commission, can provide the incentive for the European social partners to negotiate. Secondly, European institutions, and in particular the Commission and the Council, can intervene to ensure the implementation of a collective agreement by making it legally binding. We can distinguish between such statutory agreements (COCOCAs and SICOCAs) and non-statutory agreements (COSICAs and SISICAs).

The 'shadow of hierarchy' over the European social dialogue is illustrated in Table I. Using the grid of four procedural types of agreements and analysing the number and types of European collective agreements signed over the past fifteen years, this article makes three claims:

- Firstly, to be effective the European social dialogue is to a great extent dependent on the shadow of hierarchy, which is cast both by incentives to negotiate and by ensuring implementation through public intervention.

- Secondly, while the shadow of hierarchy plays an important role in the European social dialogue, the procedures on adopting collective agreements are often difficult to define in traditional principal-agent terms. The theory assumes clear delegation and the principal's control over the agent. The social dialogue appears at first sight to be a form of governance in which public authority has delegated policymaking functions to private actors within the particular sector of employment regulation. However, the reasons for delegation, the nature of delegation and the possibilities for control are often different from what principal-agent theory would suggest.

- Thirdly, this article also addresses the question - suggested as well by principal-agent theory - of whether sectoral governance (in the shadow

TABLE I

\begin{tabular}{lll}
\hline & $\begin{array}{l}\text { Implementation by Council } \\
\text { directive } \\
\text { (statutory agreements) }\end{array}$ & $\begin{array}{l}\text { Autonomous implementation } \\
\text { (non-statutory agreements) }\end{array}$ \\
\hline Commission-initiated & $\begin{array}{l}\text { COCOCA (Commission- } \\
\text { initiated and Council- } \\
\text { implemented CA) }\end{array}$ & $\begin{array}{l}\text { COSICA (Commission-initiated but } \\
\text { self-implemented CA) }\end{array}$ \\
SICOCA (self-initiated but Council- & SISICA (self-initiated and self- \\
implemented CA) & implemented CA) \\
\hline
\end{tabular}

Strongest shadow of hierarchy (in bold); weaker shadow (in italic), weakest shadow (in roman). 
of hierarchy) provides more effectiveness than hierarchical democratic government. The European social dialogue provides only very modest evidence of 'rolling back government' to ensure effectiveness.

In the first part of this article, I will show how all the earliest European collective agreements took the form of statutory agreements, and more specifically COCOCAs. Thus, the social dialogue was initially used only as a regulatory technique initiated by the Commission and implemented by Council directive, and the social partners did not pursue autonomous action. This illustrates the dependence of the social dialogue on the shadow of hierarchy. Yet, despite the shadow of hierarchy, COCOCAs are odd in principal-agent terms, characterised by unclear delegation of the regulatory task. Evidence of the effectiveness of social dialogue - an alternative to normal legislative intervention and 'rolling back government' - as a regulatory technique is mixed.

In the second part I will analyse the recent emergence of more autonomous collective agreements, namely non-statutory agreements. While the emergence of these agreements seems to contradict the argument that the European social dialogue works only in the shadow of hierarchy, a closer look reveals that even such autonomous agreements often emerge only with public incentives and that the effectiveness of their implementation proves to be highly problematic. The argument 'no effective agreements without shadow of hierarchy' thus remains, to a great extent, valid. Non-statutory agreements are hard to define in principal-agent terms when they are adopted on the initiative of the social partners (SISICAs), in which case there is no delegation by the 'government'. Yet, for non-statutory agreements initiated by Commission consultation (COSICAs), the Commission has stressed its intention to retain control as the principal over regulatory processes. However, the analysis of the non-statutory agreements also shows that the European social dialogue is not only about providing a regulatory technique alternative to traditional legislation (and thus about 'rolling back government') but it is also about more bottom-up instruments occupying a governance space where hierarchical legislation would never intervene.

\section{Statutory agreements (COCOCAs and SICOCAs)}

\section{I. The shadow of hierarchy to ensure the effectiveness of the social} dialogue

Following the introduction of the European social dialogue procedure in the Maastricht Treaty, all early European collective agreements took the 
form of COCOCAs. Agreements were signed only after an initial consultation by the European Commission and not on the initiative of the social partners. This was due to the imbalance in power position between management and labour at the European level. European employers' organisations have no particular interest in European regulation on social issues. Labour, for its part, lacks the bargaining power to get management to the negotiating table on issues it considers important. This is partially explained by the facts that 'labour at the European level' is not homogeneous and that trade unions from different member states may consider their interests to be divergent. Even if national trade union leaders may still develop a common 'European labour interest' within the framework of the European Trade Union Confederation (ETUC), it is less evident that the rank and file will develop a sense of European labour solidarity (Turner I998: I I9). Due both to divergent interests and to the large numbers of people and countries involved, the basic instruments of class struggle, such as a strike, are particularly difficult to develop at the European level.

Therefore, besides (very) soft norms which are not considered problematic by management, the European social dialogue is likely to lead to results only under the threat of legislative action. Only if management faces the risk of binding and more demanding provisions will it have an incentive to negotiate with labour. Bercusson described the process as 'bargaining in the shadow of the law' (Bercusson I994: 20; I996: 54I).

Moreover, the 'shadow of hierarchy' has proved equally important at the implementation stage of European collective agreements. Although the social dialogue provisions introduced at Maastricht provided that European collective agreements could be implemented with the means of industrial relations available at the national level, the European social partners had strong doubts about the effectiveness of this implementation route given the diversity of industrial relations in the member states and the lack of instruments available for the European social partners to ensure compliance by their member organisations (see below). Consequently, for (nearly) ${ }^{2}$ all agreements signed before 2000, the European social partners requested implementation by Council directive. In total, three European cross-sectoral agreements were signed and implemented by Council directive, namely those on parental leave (1995), part-time work (I997) and fixed-term work (I999). In all three cases, agreement among the social partners was reached only after initial consultation for legislation by the Commission. Also at the sectoral level the threat of legislation - or at least the 'shadow' of an existing legislative framework played a decisive role in the signing of the three European sectoral collective agreements that were implemented by Council directive. All three agreements deal with working time in sectors that were originally 
excluded from the Working Time Directive (93/ro4/EC). Agreements in the seafarers' sector (I998) and the civil aviation sector (2000) were signed after the Commission had announced in its white paper the intention to extend the directive to those sectors (Keller and Bansbach 200I). The 2004 agreement on working conditions of mobile workers in interoperable cross-border services in the railway sector was triggered by the special treatment for this sector in the new Working Time Directive 2003/88/EC.

Around the turn of the twenty-first century, several observers concluded that, given the dependence on hierarchy, in terms of both threat of legislation and public intervention to ensure implementation the European social dialogue was a regulatory technique rather than an additional level of bipartite negotiation in an autonomous multilevel collective bargaining system (Lo Faro I999; Bernard 2000).

\subsection{COCOCAs and principal-agent relationships}

Although the (initial) practice of the European social dialogue shows that there is a clear hierarchical relationship between the public authority and the private actors ensuring such sectoral governance, this relationship differs on several points from what could be called a strong principalagent relationship. According to principal-agent theory, governments may delegate regulatory tasks to an agent where the latter can offer better expertise and flexibility or can create longer-term credibility beyond the changing preferences of governments and daily politics. As noted above, the theory assumes that delegation is clear and that procedural guarantees allow the principal to exercise ex post control on the agent. Signing European collective agreements on the initiative of the Commission, and subsequently giving them binding force by Council directive (in COCOCAs), may appear as an alternative European regulatory technique where the public authority as principal has delegated the regulatory task to private actors as agents. Yet, the procedure for the adoption of COCOCAs is a very particular one in principal-agent terms.

Above all, agents are not 'independent authorities', but the main stakeholders in the field. The argument for delegation may be based on the fact that the social partners have expertise and can ensure flexibility by adapting to sectoral and local conditions, and may thus be more effective policy deliverers than government. Yet, the normative arguments to leave regulation directly in the hands of the stakeholders (rather than an independent authority) are related to a bottom-up approach to socioeconomic governance and traditions of the autonomy of collective bargaining, rather than to the idea of independence from daily politics and from changing interests. 
Secondly, the European social dialogue procedure (even in the form of COCOCAs) does not constitute an explicit and clear delegation to the social partners. The Commission consults the social partners on a legislative proposal, and at that point the latter can express their preference to deal with the issue by collective agreement. Yet, the principal, the Commission, does not set out a detailed regulatory task for the agent. Moreover, the social partners are autonomous: they can negotiate on what they want and are entirely free to deviate from the initial Commission proposal.

Thirdly, the principal does not appoint the agent. While the Commission has made a list of fifty-seven organisations that will be consulted on social legislative initiatives, it abides by the principle of 'mutual recognition' in collective bargaining; that is, the social partners choose who to sit with at the negotiation table.

Moreover, the principal-agent relationship is further complicated by the fact that the Commission 'delegates' to more than one agent. While there can be more than two agents - the cross-sectoral European collective agreements, for instance, have all been signed between ETUC, the Union of Industrial and Employers' Confederations of Europe (UNICE, now Business Europe) and the European Centre of Enterprises with Public Participation and of Enterprises of General Economic Interest (CEEP) - one can argue that there are normally two opposed (groups of) agents, namely employers' organisations on the one hand and trade unions on the other. The agents have opposing interests and unbalanced resources. The principal-agent relation is thus not simply one in which the principal sets out a clear task to a single agent whose performance of the delegated task is subsequently scrutinised. Instead of setting out a clear task for the agent(s), the role of the principal here is rather to induce the agents to agree, and to provide 'balanced support' to compensate for their unbalanced resources. ${ }^{3}$ Ultimately, whether the delegation is successful depends on whether the agents can agree among themselves.

While delegation is implicit rather than explicit, and the delegated regulatory task is not well defined and left to an uncertain negotiation process among opposing interests, the principal can ensure control over the agents at two stages. Firstly, while the Commission suspends its proposal to leave the social partners the opportunity to seek agreement, it can at any time invoke its power of legislative initiative if it considers that its original objectives are not achieved by the negotiation between management and labour. From this perspective, the principal finds itself in a procedurally strong position and the delegation is very provisional. The EC Treaty states that the social partners' attempts to negotiate should not take more than nine months (unless the Commission agrees 
to extend the period). In theory, the Commission can even revoke its delegation before the nine months have passed, although the Commission has always left the social partners the time they asked for, as long as they agreed further attempts were worth trying.

Secondly, before proposing the implementation of the agreement by directive the Commission retains its role as principal by controlling the regulatory task delegated to the social partners. In order to give legislative value to a European collective agreement, the Commission will verify that the following aspects have been respected:

- the agreement should contribute to the social aims of the Community, and should respect the principles of subsidiarity and proportionality of Community action;

- the content of the agreement should be in accordance with Community law, and should in particular be compatible with provisions protecting small and medium-sized enterprises;

- the signatories should be representative and have a mandate from their members;

- the agreement should be 'legitimate' with regard to the role of the non-signatory social partners and their members, i.e. mainly not upsetting their role at the national level;

- finally, the Commission will check the appropriateness of the agreement in policy terms, i.e., whether the agreement fits with existing Community policies and needs, and will express whether it can endorse the aims of the agreement.

At first sight, these checks appear to provide the principal strong control over the agent, and some have criticised them as intruding too much on the autonomy of the social partners. ${ }^{4}$ However, one should not forget that COCOCAs are by nature agreements drafted by private actors (which can deviate considerably from the original Commission initiative) and which are given the same force as binding legislation. Moreover, having accepted the principle of the autonomy of collective bargaining, the Commission has committed itself to not changing the text of the agreement when proposing it for implementation by Council directive, and it has even committed to withdrawing the proposal for implementation if the Council intends to make any change to it. Put differently, the Commission has delegated the drafting of a legislative norm entirely to the social partners and will limit itself to checking the criteria listed above without changing the text adopted by the social partners.

In addition, in practice the Commission's interpretation of these criteria is lenient. Certainly, it would be difficult to imagine that the Commission would consent to implement a cross-sectoral agreement if it were signed only by some small European social partners' associations. 
Yet, there is a case before the European Court of Justice that shows the difficulty in imposing the criteria of 'representativity': that of UEAPME, the largest European association representing small and medium enterprises (Smismans 2004: 340-3). In this case, the ECJ did not follow UEAPME's request to annul the Parental Leave Agreement, signed between the three confederal European social partner organisations, namely ETUC, UNICE and CEEP, although UEAPME had been excluded from the negotiation process of that agreement. Moreover, on other criteria such as subsidiarity and appropriateness the Commission's control has appeared even more lenient (for details, see ibid.: $3^{8} 3^{-6}$, 389-94). In fact, the Commission and Council have never refused to implement an agreement by Council directive. As principal, the Commission finds itself in a rather weak position politically. If it refuses the implementation of an agreement by directive the European social partners may lose for ever any interest in using the social dialogue procedure. For management and labour the cumbersome search for an agreement is worth the effort only if they know their document will be implemented without any change.

The procedure to adopt COCOCAs is thus characterised by an unclear, nearly implicit delegation to agents who have broad room for interpreting the delegated regulatory task but who have to come to a common agreement. As the outcome of the process is unsure, the principal retains the power to revoke the delegation at any time and will check it against the criteria before providing the agreement with binding force. While this appears formally to invest the principal with strong control powers, in practice its political room for manoeuvre is limited, since not implementing or changing a finalised agreement strongly risks emptying the social dialogue procedure of any future use.

\section{3. 'Rolling back government to ensure effectiveness?'}

As argued above, delegation of regulatory tasks to the European social partners may be justified by their particular expertise and adaptability to particular conditions, which would ensure more effective regulation. In fact, the creation of the European social dialogue procedure was inspired by the belief that such a dialogue would overcome stalemates in decisionmaking on social issues at the European level (Falkner I998: 72; Mias 2004: 664; Johnson 2005: 63).

The initial outcomes of the European social dialogue after Maastricht indeed created some optimism that such sectoral governance, 'rolling back government', would improve the effectiveness of policymaking. The first three European collective agreements - on parental leave, part-time work and fixed-term contracts - were able to regulate issues that had 
been blocked for years in the Council under the normal legislative procedure. ${ }^{5}$ However, it is difficult to assess whether social dialogue as a regulatory technique is more effective than the traditional legislative procedure.

Firstly, the initial three agreements did indeed manage to provide regulation in areas where legislation had failed, but it is not clear to what extent this 'unblocking' was due to the introduction of the social dialogue procedure, or to the facilitating of European social policy legislation with the extension of qualified majority voting on these issues by the Maastricht Treaty and the UK's temporary social policy opt-out in that period.

Secondly, the European social dialogue outcomes have been criticised for not providing much substantial content (Jacobs I998: 3i6; Fredman I998: 407, Keller 2003) although it is difficult to make such an assessment as it raises questions about what European social policy is supposed to deliver and how normal legislation would have dealt with it. In any case the number of agreements with binding effect is low; of more than twenty Article ${ }_{3} 8$ consultations ${ }^{6}$ with the social partners by the Commission on possible social legislation, only three have led to cross-sectoral agreements implemented by Council directive, and thus to sectoral governance taking priority over normal legislation. ${ }^{7}$

One can conclude that as an alternative regulatory technique - that is, instead of legislation, the Commission delegates the task of drafting the regulation to the social partners; it is then implemented by directive - the European social dialogue has a modest outcome. However, as the next section will illustrate, the social dialogue is not only about delegating the drafting of binding regulation to the social partners; it also aims to provide a more bottom-up process of softer sectoral governance.

\subsection{Addendum on SICOCAs}

In theory, agreements that are implemented by Council directive do not need to originate in an initial consultation by the Commission. The social partners could themselves take the initiative to adopt an agreement and then request its implementation by directive (SICOCAs). However, it is very hard to find an example of this. For all existing statutory agreements the process of negotiation has been triggered in one way or another by an initiative of the Commission by formal consultation under Article $138 \mathrm{EC}$ or by informal contacts and suggestions for intervention, as was, for instance, the case with the sectoral agreements on working time (as explained above).$^{8}$

In any case, even if an agreement is autonomously initiated by the social partners (and thus is not the result of any form of delegation), as 
soon as the social partners request the implementation of an agreement by directive the Commission will take up its controlling role and check the relevant criteria, as in the case of COCOCAs.

\section{Non-statutory agreements}

\section{I. The recent emergence of autonomous agreements: dialogue without} the shadow of hierarchy?

Bipartite action between the social partners at the European level is not an innovation of the Ig9os. Since the Ig6os the Commission has encouraged such dialogue by providing financial support to the social partners and creating an institutional framework in which cross-sectoral and sectoral joint committees can meet. This infrastructure has led to an impressive number of bipartite documents: joint opinions, frameworks of action, codes of conduct, guidelines, manuals and so forth. More than fifty documents have been signed at cross-sectoral level and more than $35^{\circ}$ at sectoral level (Pochet 2004: 4). However, all these instruments have been soft, and only after the Maastricht Treaty have we seen the signature of European collective agreements with binding commitments (COCOCAs), as explained above.

More recently, however, some autonomous collective agreements have been signed in which the European social partners include commitments that go beyond the soft tools traditionally characterising their autonomous dialogue. In 2002, the European social partners expressed the will to adopt European collective agreements with more autonomy from the European institutions. They planned to take the initiative themselves rather than acting after consultation by the Commission, and they would opt for the implementation of such agreements with the instruments of industrial relations available to them at the national level rather than seeking implementation by Council directive.

To create more autonomy from the Commission in setting the agenda for their negotiation, the cross-industry social partners (ETUC, UNICE and CEEP) in November 2002 adopted their first pluri-annual joint work programme for the period 2003-5. ${ }^{9}$ Moreover, they sought solutions to make 'implementation through their own means' more effective. Until then autonomous documents were merely joint opinions, codes of conduct or guidelines. If agreements were to include binding commitments, the social partners requested implementation by Council directive. The outcome of implementation of an agreement "with their own means' - in which the European social partners rely on their national member organisations and the instruments of industrial relations available to them - would be very uncertain given the diversity of national 
industrial relations systems and the absence of instruments for the European associations to ensure compliance by their national member organisations. Yet, at the beginning of the twenty-first century, the European social partners found inspiration in the benchmarking and reporting techniques applied in the open method of co-ordination (OMC) by which the European Union aims to co-ordinate national policies in the socioeconomic sphere. The social partners followed the suggestion made by the High Level Group on Industrial Relations (European Commission 2002) to introduce OMC-like methods of benchmarking and follow-up reporting into their negotiated texts. In such 'new generation texts' ${ }^{\text {IO }}$ the European social partners make recommendations to their national member organisations and undertake to follow them up by regular reporting on implementation at the national level. These documents do not provide the same binding provisions as the implementation of European collective agreements by Council directive but, by introducing benchmarking and regular reporting on the action undertaken by their member organisations, the European social partners go further than the soft commitments made in their autonomous dialogue up to that point.

At the cross-sectoral level, five such new generation texts with their own reporting systems have now been adopted: two 'Frameworks of Action', one on lifelong learning (March 2002) and another on gender equality (March 2005); and three 'Framework Agreements', on teleworking (July 2002), work-related stress (October 2004) and harassment and violence at work (April 2007). ${ }^{\mathrm{II}}$ At the sectoral level reporting systems have been introduced in an agreement regarding musculo-skeletal disorders in the agricultural sector (November 2005) and in a multi-sector agreement (April 2006) to reduce health risks associated to the use of crystalline silica. ${ }^{12}$

\subsection{Autonomous agreements and the need for the shadow of hierarchy to ensure effectiveness}

The emergence of autonomous agreements seems to contradict the preceding argument that the European social dialogue can function only under the shadow of hierarchy. However, a closer look at the signed autonomous agreements reveals that without any shadow of hierarchy the success of collective agreements is questionable. Firstly, without any incentive from the European institutions it appears unlikely that the social partners will agree even on non-statutory agreements. Secondly, the signed non-statutory agreements - lacking the binding force that could be provided by public intervention - appear highly problematic in their implementation. 
No non-statutory agreements without public pressure?

Although the European social partners attempted to set their own agenda for dialogue through their pluri-annual work programmes, even nonstatutory agreements seem to emerge only when the European institutions provide an obvious incentive for the social partners to negotiate, either by explicit consultation or invitation, or more indirectly by a cognitive framework that invites the social partners to act.

Four of the seven new generation texts emerged only after Commission consultation or after the Commission made it clear that it intended to take initiative in this field. This has been the case for the agreements on teleworking, ${ }^{\mathrm{I3}}$ stress, ${ }^{\mathrm{I}}{ }^{4}$ musculo-skeletal disorder in agriculture ${ }^{\mathrm{I5}}$ and harassment and violence at work. ${ }^{16}$

The other three new generation texts did not follow an explicit Commission initiative, but emerged nevertheless in the context of a cognitive framework set out by the European institutions. The autonomous agreement on the European licence for drivers carrying out a cross-border interoperability service of January 2004 should be seen in the context of a set of regulatory initiatives relating to the creation of the European Railway Agency for Safety and Interoperability, the Safety Directive and the Technical Specifications for Interoperability. The agreement clearly intends to take the lead on the legislation and states explicitly: 'for the part covering the scope of this Agreement, both parties want the directive to be written on the basis of this Agreement'. Put differently, the threat of likely legislation made the social partners act.

With the Frameworks of Action on lifelong learning and on gender equality, the direct threat of legislative intervention may have been less immediate. Yet, one cannot ignore the cognitive framework on these issues provided by the European institutions and the repeated invitation to the social partners to take action. With a Commission that always tests out the extent of its potential action, and a broad cognitive framework of socioeconomic guidelines and priorities as set out in the Lisbon Strategy-and to which the social partners claim repeatedly to be committed-it is difficult to see collective agreements as emerging entirely autonomously. In fact, while the work programmes presented by the social partners in 2002 and 2006 had the aim of developing action more independently from Commission's initiatives, they were also explicitly framed as a contribution to the Lisbon and the European Employment Strategies. In particular they promised initiatives on lifelong learning and on gender equality after the European Employment Strategy had invited the social partners to take initiatives in this field (Kerschen and Roussel-Verret 2006). In particular the agreement on lifelong learning saw the light in a period - following the 2000 Lisbon summit - in which the EU became very active in promoting initiatives on 
education and training, by way of both directives and guidance through an $\mathrm{OMC}$ procedure.

The picture that seems to emerge is one in which there is a clear correlation between, on the one hand, the threat or likelihood of public action and, on the other, the force and level of commitment the social partners engage in. At one end of the spectrum, really binding commitments emerge only under the clear threat of legislative action, leading to agreements implemented by Council directive. At the other end, the social partners engage entirely autonomously in a high number of soft documents and statements without any particular follow-up. In between one finds a grey zone in which the $\mathrm{EU}$ is more or less likely to intervene and in which the social partners commit to call their member organisations to action with more or less constraining procedures of follow-up.

\section{The problematic effectiveness of non-statutory agreements in terms of implementation}

There remain serious doubts about the efficiency of implementation of non-statutory agreements. There are two main problems with such implementation. Firstly, the practices and procedures available to the social partners are very different from country to country, regarding both the legal effects of collective agreements and their coverage due to levels of unionisation. This may create very diversified situations with national collective agreements having binding effect erga omnes in certain countries and other national agreements being mere gentlemen's agreements which will have effect only if taken over by the individual labour contract. Such unbalanced implementation would question the 'Community character' of the agreement (Lo Faro I999: I67). This may be acceptable if one aims at a diversified multilevel system of collective bargaining but, if the objective is also a regulatory initiative ensuring a certain level of convergence in the common market, only implementation by Council directive is likely to function as a sectoral governance alternative to legislation.

Secondly, it is entirely up to the member organisations of the European social partners to ensure the implementation of the agreement. In fact, when the social dialogue procedure was created in the Social Agreement added to the Maastricht Treaty, the member states attached a declaration regarding the procedure of autonomous implementation, stating that the member states have no obligation either to apply these agreements directly or to work out rules for their transposition, and no obligation to amend national legislation in force to facilitate their implementation.

The European social partners thus entirely delegate implementation to their national member organisations, but they have no real power of control or, even less, sanction over national organisations on their 
implementation efforts. The reporting systems of the new generation texts now provide an institutionalised link between the national member organisations and the European social partner confederations to ensure follow-up. However, to what extent will reporting to and assessment by the European social partners induce the national social partners to act? Do they feel committed to the European agreement? Do both management and labour feel committed at the national level (since they will have to agree)? And how will the opposing interests between management and labour play in the reporting system? Do they report separately or together? Do they have the resources to do this reporting? How do the European social partners evaluate and agree on the reporting?

It is very early to make an assessment of these new generation texts. It is worth noting, however, that neither the teleworking agreement nor the stress agreement has even been translated into all EU languages. According to a first assessment report on the teleworking agreement provided by the ETUG (Clauwaert, Düvel and Schöman 2005), in eight member states the implementation at the cross-industry level can be considered finalised, while in eight other countries negotiations or initiatives are under way. Yet, for the other nine member states no particular measures can be identified or the data are not available. The report mentions as especially problematic the lack of consensus between management and labour within the member states on the degree of obligation to enforce the autonomous agreement, and the absence of a clear joint interpretation of that agreement. While we will have to await future assessment of these recently adopted texts, the picture to date seems rather to suggest that such 'private implementation', without the hierarchical intervention of public authority, may at best lead to very partial implementation in some countries (and sectors).

\subsection{Principal-agent relationships and the importance of distinguishing between COSICAs and SISICAs}

As illustrated above, it is not always easy to identify whether one is dealing with a SISICA or a COSICA. The distinction, however, is important. In its 2004 communication on social dialogue, the Commission, while 'fully recognising the negotiating autonomy of the social partners', stressed that 'in the specific case of autonomous agreements implemented in accordance with Article 139(2), the Commission has a particular role to play if the agreement was the result of an Article I38 consultation, inter alia because the social partners' decision to negotiate an agreement temporarily suspends the legislative process at Community level initiated by the Commission in this domain' (European 
Commission 2004). Put differently, the Commission stresses its established right to take initiative for legislation. While having put regulation in the hands of the social partners, as a consequence of consultation, the Commission will nevertheless examine whether or not the autonomous agreement succeeds in meeting the Community's objectives. The principal will thus control the agent on the delegated task and check whether an autonomous agreement - in its content (ex ante) and in its implementation (ex post) - ensures the objectives of the initial Commission initiative. Should the Commission decide that the agreement does not succeed in meeting the Community's objectives, it will consider the possibility of putting forward, if necessary, a proposal for a legislative act (ibid.).

The social partners are not very happy with this 'intrusion' by the Commission into their autonomous dialogue. The question of whether an autonomous agreement has been initiated by Commission initiative (COSICA) - and is thus the object of Commission control - or entirely by the social partners (SISICA) - thus not being an object of control thus tends to become a sensitive issue of interpretation. This was the case with the discussion surrounding the Agreement on Work-Related Stress. The agreement emphasises in its introduction that the European social partners' work programme for $2003-5$ had identified the need for joint action in this field, thus anticipating the Commission consultation on stress. Yet, the fact that the social partners had included the issue in their work programme did not prevent the Commission from initiating - two weeks after the publication of the programme - a consultation process on this issue. This creates the shadow of hierarchy over the autonomous dialogue by putting the social partners, and in particular management, under pressure to take the promise to negotiate seriously, and justified the Commission's assessing the outcome. This has not been particularly welcomed by the social partners, or at least by some of them, as demonstrated an employer representative defining the Commission initiative as 'a highly unconstructive and inappropriate consultation' and ' a stab in the back of the social dialogue'. ${ }^{17}$ The initiative, it was argued, had come from the social partners and the final agreement should thus be considered a SISICA.

\section{4. 'Rolling back government to ensure effectiveness?'}

As a regulatory technique alternative to legislation, non-statutory agreements do not constitute a successful example of 'rolling back government' given their problematic implementation. However, under current conditions, for those in favour of more European social policy intervention non-statutory agreements may turn out to be the only available 
option. In particular, since the enlargement of the EU to twenty-seven member states, the legislative route to social policy intervention fails to deliver, since many of the new members see no value in further European social regulation. As a consequence, also, statutory agreements are no longer signed, since the threat of legislation is missing; that is, management does not feel any pressure to enter into strictly binding commitments with labour. For labour, the signing of non-statutory agreements with their own reporting mechanisms may then be 'as good as it gets'. At the same moment, management seems to have lost its antipathy towards non-statutory agreements, which it initially regarded as opening the door to a real European industrial relations system it did not particularly want to engage in. Due to enlargement, non-statutory agreements are likely to remain soft instruments with strong flexibility in implementation, and thus will no longer be feared by management (Branch 2005: 334).

From a pro-social policy perspective, then, the current state of affairs of the European social dialogue may be a 'U-turn back to the pre-Maastricht status of non-binding recommendations and the period of "joint opinions" and the continuation of 'regulatory minimalism' (Keller 2003: 426). Another perspective may hold that social dialogue is not only an alternative regulatory technique to provide binding commitments in some way other than by legislation, but also a multilevel governance process leading to more or less binding outcomes. Some of the issues addressed in the social policy field arguably lend themselves less easily to a legislative approach, and autonomous initiatives of the social partners would also allow for action in areas where no Commission initiatives are foreseen (Branch 2005: 336). Social dialogue is then less about 'rolling back government' than about 'complementing government'. However, in the current situation, non-statutory agreements seem to be more about acting in the absence of government, and it is difficult to prove the effectiveness of such action.

\section{Conclusion}

The history of the European social dialogue shows its strong dependence on the shadow of hierarchy. After the Maastricht Treaty introduced the social dialogue procedure, all initial agreements emerged only on the initiative of the Commission, and to ensure the effectiveness of their implementation the social partners always requested that the Council intervene by adopting a directive. The emergence of non-statutory agreements since 2000 does not provide a convincing argument that social dialogue could do without the shadow of hierarchy. Even these non-statutory agreements have emerged only when the EU provided 
incentives. In particular, the more non-statutory agreements come close to binding commitments, the more EU initiative appears to have been fundamental in their emergence. Moreover, the problematic implementation of non-statutory agreements casts doubts on the viability of agreements that do not rely on hierarchy to ensure their application.

While the shadow of hierarchy is important to ensure the effectiveness of the social dialogue, the social dialogue procedures are not characterised by strong principal-agent relationships. Even when agreements result from initial Commission consultation, there is no clear delegation to the social partners. Moreover, the Commission does not appoint the agents and successful delegation entirely depends on whether these agents reach an agreement between themselves. While the risk of failure is high, the Commission has the right to 'revoke the delegation' at any time. The Commission will also take up its role as principal in assessing a set of criteria if the social partners ask for implementation of their agreement by directive. Yet, even for statutory agreements, the Commission's 'room for manoeuvre' to compel adherence to these criteria is limited for reasons of political pragmatism.

For non-statutory agreements, the principal-agent relationships differ according to whether the Commission has initiated the process or not. If not, non-statutory agreements can hardly be defined in principal-agent terms. They emerge as a bottom-up process akin to ideas of legal pluralism and autonomy of industrial relations, rather than as a delegation of regulatory tasks. However, if non-statutory agreements do originate in a Commission consultation, the Commission considers this to be a delegation of its regulatory tasks and will determine whether such agreements conform to the Community's regulatory objectives.

Finally, can the European social dialogue be described as a successful example of rolling back government to ensure better policy outcomes? The first statutory agreements were adopted in fields where legislation had failed, but this may have been due to a combination of elements of institutional change. Moreover, whether the regulatory content is better than what would have been achieved with ordinary legislation is difficult to assess.

It is obvious that the more recent non-statutory agreements, given their problematic implementation, appear weak as an alternative to legislation. One could argue, however, that the social dialogue is not only about providing a regulatory mechanism alternative to legislation, but also about offering more or less binding commitments at multiple levels where legislation would never have been adopted. Yet, rather than 'complementing government', the current social dialogue looks like not-too-effective governance in the absence of government. 


\section{NOTES}

I. I would like to thank Nieves Pérez-Solórzano Borragán and Edward Best for useful comments.

2. At the sectoral level two agreements had already been presented as 'autonomous agreements' by the social partners: a 'Recommendation Framework Agreement on the Improvement of Paid Employment in Agriculture in the member states of the European Union' in I997 and an agreement on working time in the railway sector in I998. Both 'agreements' are soft guidelines to their national member organisations, without any form of reporting or control that may give a minimum level of bindingness to the commitments. For the soft nature of the agreement in agriculture, and the lack of implementation of it, see Franssen 2002: 335 .

3. The Commission has provided financial support to strengthen the organisational structure and expertise of the social partners at the European level, in particular via support to the 'weaker party' in the European social dialogue, namely the European Trade Union Confederation.

4. It has been argued that these checks make implementation of a collective agreement by directive much more political than such procedures at national level (Delarue I998: I85; Jacobs I998: 319).

5. The first Commission initiatives on parental leave, for instance, date back to i983 (Delarue ig98: I75).

6. A list is available at ec.europa.eu/employment_social/social_dialogue/consultations_en.htm.

7. Failure to agree does not make the consultation procedure unimportant, since the social partners' opinions expressed may still influence the legislation that may be adopted in case negotiation fails. See Falkner i996: 5; Cullen and Campbell i998: 279.

8. The European agreement on certain aspects of the working conditions of mobile workers assigned to interoperable cross-border services of 2004 would come closest to the definition of a SICOCA. There was no formal or informal consultation or invitation by the Commission, but the agreement was, nevertheless, a reply to a specific existing European legislative framework.

9. Renewed with a new work programme adopted in March 2006.

Io. The concept was introduced by the Commission (European Commission 2004: I3).

II. The distinction between a Framework of Action on the one hand and an autonomous (Framework) Agreement on the other is not easy to draw, although the Commission - in search of conceptual clarity - suggests that it is an autonomous '(Framework) Agreement' when the document is to be implemented and monitored by a given date according to the process provided in it, whereas 'recommendations' or Frameworks of Action would entail regular reporting and follow-ups over a longer period without a specific deadline by which results need to be achieved (European Commission 2004: 7).

I2. Agreement on workers' health protection through the good handling use of crystalline silica and products containing it, 25 April 2006.

I3. EIRR 2002; and EIROline, www.eiro.eurfound.eu.int/2002/o7/feature/euo207204f.html.

I4. List of consultations at ec.europa.eu/employment_social/social_dialogue/consultations_en.htm.

I5. EIROnline, www.eiro.eurofond.eu.int/2006/o2/inbrief/euo6o2202n.html.

I6. Press Release by Businesseurope, ETUC, CEEP and UAPME, 26 April 2007.

I7. Interview with European employer representative, Brussels, April 2006.

\section{REFERENCES}

Bercusson, B. (I994) 'The Dynamic of European Labour Law After Maastricht'. Industrial Law Fournal, $23, \mathrm{I}-3 \mathrm{I}$.

Bercusson, B. (I996) European Labour Law. London: Butterworths.

Bernard, N. (2000) 'Legitimising EU Law: Is the Social Dialogue the Way Forward? Some Reflections Around the UEAPME Case', in J. Shaw (ed.) Social Law and Policy in an Evolving European Union. Oxford: Hart, pp. 279-302.

Branch, A. (2005) 'The Evolution of the European Social Dialogue Towards Greater Autonomy: Challenges and Potential Benefits'. International Journal of Comparative Labour Law and Industrial Relations, 2I, 2, 32I-46.

Clauwaert, S., Düvel, W. and Schöman, I. (2005) 'Assessment Report on the Teleworking Agreement'. European Trade Union Confederation working document, 9 November.

Cullen, H. and Campbell, E. (I998) 'The Future of Social Policy-Making in the European Union', in P. Craig and C. Harlow (eds.) Lawmaking in the European Union. London: Kluwer Law International, pp. $262-84$. 
Delarue, R. (I998) 'De Europese kaderakkoorden over ouderschapsverlof en deeltijdse arbeid: voorbereiding, totstandkoming, omzetting en perspectieven'. Paper presented at the Conference 'Sociaal Actieprogramma-Europese Sociale Dialoog' organised by ACW in the European Parliament, November.

EIRR (2002) 'Telework Agreement Breaks New Ground'. European Industrial Relations Review, 343 (August), I3-I6.

European Commission (2002) 'Report of the High Level Group on Industrial Relations and Change in the European Union'. Directorate General for Employment and Social Affairs, January.

European Commission (2004) Communication on 'Partnership for Change in an Enlarged Europe Enhancing the Contribution of European Social Dialogue'. I2/8/2004, COM(2004) 557 final.

Falkner, G. (I996) 'The Maastricht Protocol on Social Policy: Theory and Practice'. Fournal of European Social Policy, 6, I-I6.

Falkner, G. (1998) EU Social Policy in the Ig9os: Towards a Corporatist Policy Community. London: Routledge.

Franssen, E. (2002) Legal Aspects of the European Social Dialogue. Antwerp: Intersentia.

Fredman, S. (I998) 'Social Law in the European Union: The Impact of the Lawmaking Process', in P. Craig and C. Harlow (eds.) Lawmaking in the European Union. London: Kluwer Law International, pp. 386-4II.

Jacobs, A. (1998) 'From the Belgian National Labour Council to the European Social Dialogue', in C. Engels and M. Weiss (eds.) Labour Law and Industrial Relations at the Turn of the Century: Liber Amicorum in Honour of Roger Blanpain. The Hague: Kluwer Law International, pp. 305-28.

Johnson, A. (2005) European Welfare States and Supranational Governance of Social Policy. Houndmills: Palgrave.

Keller, B. (2003) 'Social Dialogues - The State of the Art a Decade After Maastricht'. Industrial Relations fournal, 34, 5, 4II-29.

Keller, B. and Bansbach, M. (200I) 'Social Dialogues: An Interim Report on Recent Results and Prospects', in B. Towers and M. Terry (eds.) European Industrial Relations: Industrial Relations Fournal Annual Review 1999/200o, Oxford: Blackwell, pp. 65-86.

Kerschen, N. and Roussel-Verret, I. (2006) 'Stratégie européenne pour l'emploi et dialogue social: vers la construction d'un modèle europèen de relations professionnelles'. Lien Social et Politiques, 56.

Lo Faro, A. (I999) Funzioni e finzioni della contrattazione collettiva comunitaria, Milan: Giuffrè Editore.

Mias, A. (2004) 'Du dialogue social européen au travail législatif communautaire: Maastricht, ou le syndical saisi par le politique'. Droit et Société, 58: 657-79.

Pochet, P. (2004) 'The Emergence and Evolution of the Sectoral and Interprofessional Social Dialogue? A Quantitative Analysis'. NEWGOV oi/Di5.

Schiek, D. (2005) 'Autonomous Collective Agreements as a Regulatory Device in European Labour Law: How to Read Article I39 EC'. Industrial Law Fournal, 34, I, 23-56.

Smismans, S. (2004) Law, Legitimacy and European Governance: Functional Participation in Social Regulation. Oxford: Oxford University Press.

Treu, T. (I996) 'European Collective Bargaining Levels and the Competences of the Social Partners', in P. Davies, A. Lyon-Caen, S. Sciarra and S. Simitis (eds.) European Community Labour Law: Principles and Perspectives. Oxford: Clarendon, pp. I69-87.

Turner, L. (I998) 'The Europeanization of Labour: Structure Before Action', in E. Gabaglio and R. Hoffmann (eds.) The ETUC in the Mirror of Industrial Relations Research. Brussels: European Trade Union Institute Press, pp. I I9-32.

\section{STIJN SMISMANS}

European Studies and European Law

University of Cardiff

Reader in European Law (School of Law)

Law Building

Museum Avenue

Cardiff CFIo $3 A X$ United Kingdom

http://wwrw.smismans.eu

e-mail:smismanss@cardiff.ac.uk 